In the bank
$\begin{aligned} & \text { Japan faces struggle } \\ & \text { to amass world-class } \\ & \text { tissue collection } \\ & p 754\end{aligned}$

\title{
Stem-cell giveaway proposed as confusion reigns over cell count
}

\section{Jonathan Knight, San Francisco}

Academic researchers in the United States should soon be able to access certain human embryonic stem-cell lines for free.

BresaGen, a company based in Adelaide, Australia, and ES Cell International (ESI) in Singapore say they plan to give their cells away to publicly funded scientists.

In return, the companies will ask for first rights to license any therapeutics and medical procedures that emerge from the research. The companies have developed ten human embryonic stem-cell lines between them.

The offer contrasts with the $\$ 5,000$ flat fee charged by the Wisconsin Alumni Research Foundation (WARF), which holds the US patent to human embryonic stem cells. WARF's private, non-profit laboratory says its fee is less than the cost of producing the cells.

Representatives from BresaGen will this week meet with officials in Washington to discuss how the company will distribute its cells to researchers funded by the National Institutes of Health (NIH). Meetings

between the NIH and the holders of other stem-cell lines are also being planned.

Allan Robins, BresaGen's chief scientist, says that one option being considered is a single, independent distribution centre that would handle all the cell lines for which federal funding will be permitted under rules announced by President George W. Bush on 9 August.

Such a centre could include all 60 of the

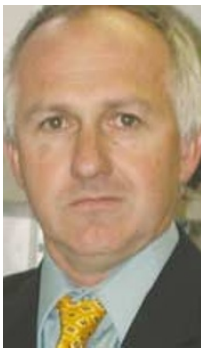

Cell for nothing:

BresaGen's chief scientist Allan Robins. stem-cell lines that the NIH says exist -45 or so of which are not accounted for by WARF, ESI or BresaGen. The sources of these cells have not yet been identified, and many scientists are sceptical about their existence.

On 17 August, the American Association for the Advancement of Science (AAAS), one of the largest US scientific soci-

\section{Partners turn to court over stem-cell rights}

Within days of President Bush's announcement on the funding of stem-cell research, the first of many likely legal battles over stem-cell technology rights was underway.

On 13 August, just four days after Bush's statement, the Wisconsin Alumni Research Foundation (WARF) filed a lawsuit in an effort to keep its private partner Geron of Menlo Park, California, from taking too large a piece of the commercial pie. WARF holds the patent on human embryonic stem cells in the United States.

But shortly afterwards, both parties issued a statement saying that, despite the lawsuit, they were still negotiating with each other on the patent, and that they expect to resolve the matter "in the near future".

Geron sponsored the research of James Thomson at the University of Wisconsin in Madison, who in 1998 derived the first human embryonic stem cells. In return, WARF, through which many University of Wisconsin inventions are patented, granted Geron limited rights to the technology.

Under the agreement, Geron has the right to commercialize any applications involving six of the more than 200 cell types in the human body - liver, muscle, nerve, bone, blood and the insulinproducing pancreatic islet cells. At the end of July, Geron exercised an option in the contract to claim an additional 12 cell types. But WARF argues in the suit that not only had the option expired a week earlier, but that it could also be denied at WARF's discretion.

Although any cell type can be derived from embryonic stem cells, some are more likely to yield commercially viable therapeutics than others. WARF is seeking to keep some of the more promising cell types available to other researchers.

"We couldn't figure out a way to resolve this without a third party," says WARF spokesman Andrew Cohn. He says WARF and Geron have been negotiating the option for seven months.

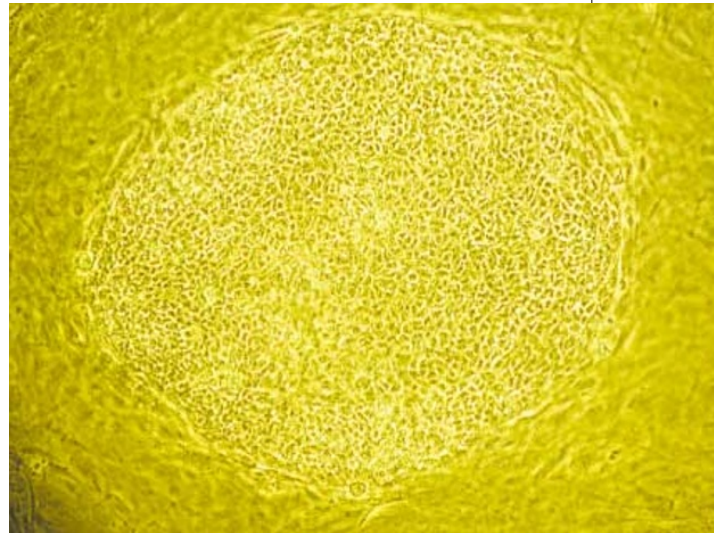

Sharing culture: BresaGen's stem cells could soon be available free of charge to researchers.

eties, issued a strongly worded statement calling on the Bush administration to publish the source of these stem-cell lines immediately.

Noting that Bush's policy depends heavily on the existence of the cell lines, the statement said that "it is essential that confusion over the actual number available be resolved as soon as possible". It also raised questions about whether cell lines derived abroad would meet US ethical standards. As of 20 August, the White House had made no response to the statement.

BresaGen has four of the known human embryonic stem-cell lines, which it derived at its US laboratory in Athens, Georgia. Robins says the company hopes to provide the cells to researchers free of charge. "We would like to be giving the cell lines away so they can be used as much as possible," he says.

ESI says it has already agreed to provide two of its six embryonic stem-cell lines to 15 laboratories worldwide, including several in the United States, for the cost of shipping.

ESI's lines were developed a year ago by a team of researchers headed by Alan Trounson at Monash University in Victoria, Australia (see Nature Biotech. 18, 399-404; 2000).

"We are getting two or three requests a day since the Bush announcement," says ESI operations manager Catriona King.

Despite researchers' fears about the terms of access to stem-cell lines, the companies that have derived them appear keen to get 
them into laboratories as quickly as possible. BresaGen and ESI also say researchers will be free to patent any invention they develop using the cells. The companies profits will come from commercializing therapies that emerge from the research.

"First options have become the standard," says Mary Ellen Sheridan, associate vice-president for research at the University of Chicago. Researchers and their institutions rarely object because private companies are better able to handle the cost of clinical trials and marketing. And most options expire within a year, after which the researcher can take the invention elsewhere, Sheridan says.

WARF, by contrast, will try to recover its investment by exercising its broad patent rights to human embryonic stem cells. The foundation does not ask for the option to license researchers' inventions, because any company that markets such an invention in the United States will have to pay WARF for a commercial licence to the underlying technology.

But some intellectual-property experts say WARF's patent is so broad it may be challenged in court."When you have a broad patent there is the possibility that broad claims will be held invalid and you will be left with a narrower patent," says Rebecca Eisenberg, a specialist in biotechnology patent law at the University of Michigan.

\section{Riders on the storm provoke studies of Atlantic dust}

\section{Rex Dalton, San Diego}

US researchers are planning an extensive study programme following reports that atmospheric dust may be transmitting microorganisms between continents.

Results collated at a workshop held on 14-15 August in Florida will be used as the basis for a grant application to the National Science Foundation early next year, participants say. They hope that the foundation will support the investigation as part of its biocomplexity programme.

Organized by the US Geological Survey (USGS), the workshop brought together 50 scientists from 18 institutions and government agencies.

Participants say recent studies suggest that clay dust from the Sahara desert — particularly from Mali — might be transporting fungi, viruses and chemical contaminants to the Caribbean, the Gulf of Mexico and the southern United States.

For instance, Aspergillus sydowii, which causes disease in Caribbean sea fans, is a possible culprit in the retreat of coral reef in the Caribbean. The fungus has been found in aerosols collected in the Virgin Islands, which are hit by dust storms swept across the Atlantic Ocean from June to October.

Researchers are also studying dust as a cause of the rising number of asthma cases in Barbados and Puerto Rico. Eugene Shinn, a USGS geologist, has even suggested that longrange dust storms could transport the virus that causes foot-and-mouth disease in livestock. He admits there are no data to support this hypothesis, but says that satellite photos from February show a storm sending plumes of African dust over Britain shortly before the outbreak of the disease there.

Ginger Garrison, a marine ecologist at the USGS Center for Coastal Geology in St Petersburg, Florida, says research is planned to analyse dust samples in the mid-Atlantic during storm episodes to compare them with samples from Mali and the Virgin Islands. "We have found quite a load of microorganisms hitchhiking on dust particles across the Atlantic," she says.

The researchers also hope to coordinate with the Asian Pacific Regional Aerosol Characterization Experiment, which has studied dust movements from the Gobi Desert to the western United States.

\section{Japan banks on tissue store for successful drugs}

\section{David Cyranoski, Tokyo}

A Japanese foundation is set to open a major tissue bank by the end of this year, in a move that pharmaceutical companies hope will bolster drug discovery and clinical research in the country.

Researchers agree that Japan needs such a bank to provide ready access to useful tissue samples, and to bring it in line with what is available in the United States and Europe. But some worry that filling the bank will not be easy.

The bank will be run by the Japan Health Sciences Foundation, a governmentaffiliated organization based in Tokyo. Under the plan, tissues including liver, lung and kidney removed during surgery would be stored at a facility in Osaka built by the foundation last year. This would then supply tissue material to both pharmaceutical companies and academic researchers on a non-profit basis.

"The bank will greatly increase research productivity and help companies compete with those overseas," says Kazutaka Ichikawa, senior managing director of the Japan Pharmaceutical Manufacturers Association. Many drug companies already

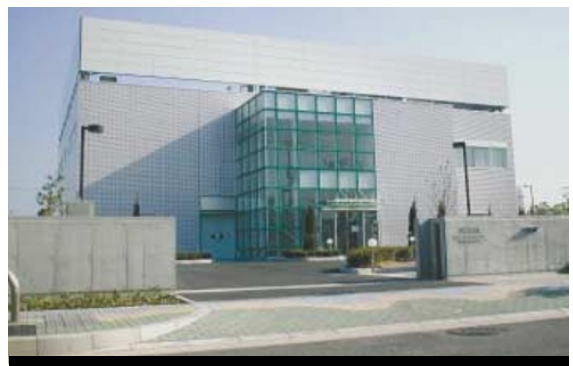

Deposit account: researchers worry that Japan won't find enough donors for its tissue bank.

contribute money to the foundation, which has provided them with cell lines and DNA samples for several years.

An official at the health ministry, which oversees the foundation's activities, says the bank will initially depend on tissue collected from eight hospitals in the Tokyo area.

Researchers will use the tissues to experiment with candidate drugs that have proved effective on animals, but are not yet approved for use in human clinical trials, foundation officials say. "This is standard in the United States and Europe, but it is still immature in Japan," says Tetsuo Sato, chairman of the non-profit Human and
Animal Bridge Discussion Group.

But the tissue bank will only work if doctors can persuade their patients to provide the necessary, explicit consent. A 1996 law forbids the use of organs in research if they were taken from people who only gave consent for them to be used in transplantation.

As a result of the law, human tissue samples are in short supply in Japan, and researchers have to import samples from the United States or rely on overseas partners to do the work.

Ichikawa and others hope that the presence of an official bank and strict enforcement of informed consent guidelines will help to win the confidence of patients and doctors.

But Masanori Fukushima, an epidemiologist at Kyoto University, says that Japan's existing legal framework will make it difficult for the new bank to receive enough donations. "Guidelines on informed consent were only in place since last year and they have no binding power," he says, arguing that clearer laws are needed to punish doctors or researchers who violate patients' rights to privacy and informed consent. 